\title{
STANDARDIZATION THE EFFECT OF PLANT GROWTH REGULATORS ON IN VITRO PROPAGATION OF BANANA (MUSA SPP) EXPLANTS: A REVIEW
}

\author{
Kothula Pravalika \\ Department of Horticulture, Lovely Professional University, Phagwara, Punjab
}

\section{ABSTRACT}

Banana (Musa spp.) is a large herbaceous perennial monocotyledonous and monocarpic plant. It belongs to the family Musaceae. Banana is one of the popular berry fruit which is available to every common person. Banana crop is mostly cultivated through sword suckers, for ease production some in vitro propagation methods came into existence like tissue culture technology. Some of them are micro propagation, clonal propagation etc, For in vitro growth of the excited tissues, plant growth regulators have been considered as one of the most significant factor. Most commonly, auxins and cytokinins are used in the growth and development of the banana explants. The plant growth regulators are required in different concentrations along with Murashige and Skoog media for the best shooting and rooting of the explants.

Keywords: Plant growth regulators, Concentrations, Media, Sword suckers, Tissue culture.

\section{INTRODUCTION}

Banana (Musa spp) is one of the tropical fruit belonging to the family Musaceae, genus Musa. Banana is the second most important fruit crop in India next to mango. The fruit is valued worldwide due to its flavour, nutritional value, and availability throughout the year. Bananas are mostly derived from the wild ancestors: Musa accuminata and Musa balbisiana (Lehmann et al., 2002). Its origin is
South-east Asia and also native to India and Western Pacific (Carreel et al., 2002). The most edible banana cultivars are derived from inter/intra specific hybridization of diploid $(2 \mathrm{n}=2 \mathrm{x}=22$; $\mathrm{AA}$; $\mathrm{BB}$ or $\mathrm{AB})$, triploid $(2 \mathrm{n}=3 \mathrm{x}=$ 33; $\mathrm{AAA}$; $\mathrm{AAB}$; or $\mathrm{ABB})$ and tetraploid $(2 \mathrm{n}=4 \mathrm{x}=44$; AAAA; AAAB; or ABBB) from subspecies of Musa accuminata (A genome) and Musa balbisiana (B genome) (Onildo et al., 2013; Pillay et al., 2006; Simmonds and Shepherd., 1995).

Examples of some common cultivars (with emphasis on cultivars grown in India) (Venkatachalam, 2008):

\begin{tabular}{|l|l|l|}
\hline Genomic Group & Sub-group & Common cultivars \\
\hline AA & Sucrier & Matti, Kadali, Anai koomban, Chingan \\
\hline AB & Ney Poovan & Ney poovan, safed velchi, Soneri, Devabale, Elakki bale \\
\hline AAA & Dwarf Cavendish & Basrai, Loton, Kabuli, Mauritius, Bhusaval, Pachabale \\
\hline & Giant Cavendish & Bombay green, Pedda pacha arati, Harichal \\
\hline & Mysore & Poovan, Lal velchi, Champa, Karpura chakkarakeli \\
\hline & Silk & Rasthali, Malbhog, Sabari, Rasabale, Amrithapani, Mutheli \\
\hline
\end{tabular}

*Corresponding author: pravalikakothula1997@gmail.com 


\begin{tabular}{|l|l|l|}
\hline AAB & French Plantain & Nendran, Rajeli, Ethakai \\
\hline & Pome & Virupakshi, Sirumalai, Vannan, Dacca martaban \\
\hline ABB & Bluggoe & Monthan, Kanchkala, Madhurangabale, Peyan, Khasadia \\
\hline & Pisangawak & Kostha bontha, Pey kunnan, Manuva kola \\
\hline AABB & & CO-1 (A new hybrid) \\
\hline
\end{tabular}

India leads the world in banana production with an annual output of about 14.2 million tonnes. Banana ranks first in production and third in area among all other fruit crops in India. It accounts $13 \%$ of total area and $33 \%$ of its total production. Maharshtra (3924.1 thousand tonnes) is the state which is highest in production followed by Tamilnadu (3543.8 thousand tonnes). Banana grows well in deep loamy soil with $\mathrm{pH}$ 6.5-7.5 along with temperature range of $15-35^{\circ} \mathrm{C}$ and relative humidity of $75-85 \%$. Suckers (Sword suckers) are used as the planting material for cultivation. Tissue culture seedlings are also used by 30\% of farmers as propagating material (IHD, 2014).

Bananas are a healthy source of fibre, potassium, vitamin B6, vitamin $\mathrm{C}$ and various antioxidants and phytonutrients. Bananas are mostly categorized into two types. They are 1) Dessert banana; and 2) cooking banana. Sweet dessert bananas are generally eaten raw (fruit), while cooking bananas and plantain are boiled, steamed, roasted and fried. In the ripening process, the starch is converted to sugar; a fully ripened banana contains only 1-2\% starch (Forsyth, 1980).

Plant growth regulators are the chemical substances which are responsible for the growth and development within the plants. These are also referred with other names like phytohormones and plant growth hormones. The maintenance of specific and balanced organic and inorganic contents in growing tissues is caused by the single or combination of different hormones in the medium. This leads the cells or tissues to develop either into shoots or roots or even death (Ikram-ul-Haq and Dahot, 2007, Raghavendar et al., 2019).

Plant growth regulators play a vital role in determining the development and development pathway of the plant cells as they act as the media components. Different proportions of growth regulators are used to break the dormancy and also to enhance the formation of shoots as it is well demonstrated that the apical dormancy is under the control of these plant growth regulators (Madhulatha et al., 2004). Cytokinins such as Benzylaminopurine (BAP) and Kinetin are very well-known to reduce the apical dominance and induce both axillary and adventitious shoot formation from meristematic explants in banana (Jafari et al., 2011). The growth and differentiation of culture cells and tissues is seen by the application of auxins and other growth regulators like gibberellins (Alexandrova et al., 1996; Bohidar et al., 2008).

Auxins like Naphthalene acetic acid (NAA) have been reported to promote the best plant rooting in vitro (Vuylsteke, 1989; Hussein, 2012). The most commonly preferred cytokinin is $\mathrm{N}^{6}$-benzylaminopurine (BAP) (Vuylsteke, 1989). Shoot proliferation rate and elongation are influenced by the cytokinin types and their concentrations due to the influence of genotypes. In several Musa spp. for in vitro propagation, adenine-based cytokinins were used (Gubbuk and Pekmezci, 2004).

\section{ROLE OF AUXINS AND CYTOKININS ON SHOOT TIP CULTURE OF BANANA (MUSA SPP) EXPLANTS}

W. C. Wong. (1986) reported about the in vitro propagation of banana (Musa spp.): initiation; proliferation and development of shoot tips using culture media with explants. Murashige and Skoog medium containing 6 benzylaminopurine (BAP) and indolebutyric acid (IBA) was taken to culture a total of 22 banana cultivars successfully. These cultivars showed a wide variation in their multiplication rates in response to cytokinins, the BAP showed consistent effectiveness than kinetin (Kn).

A micro propagation protocol for banana (Musa spp) cv. Agnishwar was done by using shoot tip cultures. Shoot tips were obtained from suckers removing the leaf sheaths and cultured aseptically on MS medium supplemented with the different concentrations of cytokinins i.e. 6benzylaminopurine (BAP), Kinetin (Kn), N6 - (2isopentyl) adenine for multiplication of shoots and auxins such as Indole-3- butyric acid (IBA), a Napthalene acetic acid (NAA) for rooting. MS medium containing $4 \mathrm{mg} / \mathrm{l}$ BAP showed maximum multiplication (95\%). The highest average no. of shoots per each explant (5.9) was found in MS medium having 4mg/l BAP while maximum elongation of shoots (4.9) was observed with $5 \mathrm{mg} / \mathrm{l}$ BAP. The concentration of $1.0 \mathrm{mg} / \mathrm{l}$ of IBA was found suitable for the rooting of shoots (Rahman et al., 2013). 
Shahnawaz Ahmed et al. (2014) In vitro multiplication of banana (Musa spp.) cv. Grand Naine reported that Murashige and Skoogs (MS) medium with BAP 4.0mg/l and with IAA $2.0 \mathrm{mg} / \mathrm{l}$ resulted in more number of cultures in less time along with more multiple shoots. Maximum rooting was attained with the concentrations of 1mg/l IBA and 200mg/l activated charcoal on MS medium. Many other studies have reported the use of auxins and cytokinins in tissue culture. Gubbuk and Pekmezci (2004) reported that the shoot proliferation rate was increased by the moderate concentrations of cytokinins, but very high concentrations decreased multiplication and mostly shoot elongation. Thidiazuron (TDZ) resulted in high shoot proliferation and elongation than with BAP. However, BAP above $20 \mu \mathrm{M}$ and TDZ over $2 \mu \mathrm{M}$ decreased the shoot elongation. Thidiazuron inhibits the shoot elongation. In another study, TDZ at $0.91 \mu \mathrm{M}$ induced the largest number of shoots, but elongation of shoots and clumps of small globular buds appeared at the base of shoots with higher concentrations of TDZ at 9.1 $\mathrm{MM}$ (Shirani et al., 2011).

M. H. Ferdous et al. (2015) studied on BAP and IBA pulsing for in vitro multiplication of banana cultivars through shoot tip culture. MS medium along with different concentrations of BAP $(0.0,1.0,2.0,3.0,4.0,5.0,6.0$, and $7.0 \mathrm{mg} / \mathrm{l})$ and IBA $(0.0,1.0,2.0,3.0,4.0$, and $5.0 \mathrm{mg} / \mathrm{l})$ was used to assess the influence on in vitro shoot regeneration and subsequent root formation of Amritsagar and Sabri banana cultivars. Under ex vitro conditions the survival rate of the plantlets of both cultivars was more than $82 \%$. MS media along with the concentrations of $0.5 \mathrm{mg} / \mathrm{l}$ BAP and $0.3 \mathrm{mg} / \mathrm{l}$ IBA can be used for shoot and root formation of Amritasagar and Sabri banana cultivars through shoot tip culture.

Another study was carried out at the Tissue Culture Laboratory of Melkassa Agriculture Research Centre, Ethiopian Institute of Agricultural Research (EIAR) to investigate the effects of different types and concentrations of cytokinins and auxins on shoot initiation and multiplication, and in vitro rooting of shoots of three banana varieties using shoot tip explants. The combination of BAP and indole-3-acetic acid with MS medium at 3+0.4, 4+0.4, and 3+0.2 mg/l for Dwarf, Giant and Poyo respectively, were best combinations for higher shoot proliferation rate and elongation. When MS medium with the concentrations of $2.12 \mathrm{mg} / \mathrm{l} \alpha$-naphthalene acetic acid (NAA) for Dwarf and Giant while $1.74 \mathrm{mg} / \mathrm{l}$ indole-3butyric acid (IBA) for Poyo showed the better rooting when the shoots were cultured (Asmare et al., 2012).
In a study on effects of cytokinin/auxin combination on shoot proliferation on banana cultivars, Arinaitwe et al. (2000) reported that the shoot proliferation rate of the banana cultivars was suppressed due to the incorporation of a strong auxin in the media. For example, the East African Highland banana (AAA-EA) showed single shoot development and callus induction on media modified with low (cytokinin/auxin ratios,16.8/1.0 and 16.8/1.2 ZN/NAA) due to apical dominance resulted from increased level of auxin concentration. In other study, Buah et al. (2010) that the differences existed in the relative strengths of different cytokinin types in shoot induction. The factors such as stability, mobility and the rate of conjugation and oxidation of hormones are attributed due to the differential ability of different hormones in inducing shoots in vitro.

Zaffari et al. (2000) reported that 2ip is a major cytokinin occurred naturally in banana tissues. In other way, the application of 2ip to shoot-tip cultures of banana (Arinaitwe et al. 2000), Canna indica (Kromer and Kukulczanka, 1985) and Manila hemp (Mante and Tepper, 1983) didn't prove effective when compared to BA and Kn applications. Arinaitwe et al. (2000) attributed the lacking in growth promotion of explants by 2ip due fact that is easily decomposed by cytokinin oxidase.

\section{ROLE OF CARBON SOURCES ON IN VITRO ROOT AND SHOOT MULTIPLICATION OF BANANA EXPLANTS}

Sugar acts as a major transport metabolite and involves in the osmotic process for the uptake of nutrients from the medium (Lalonde et al., 1999). In the study, four carbon sources at three different concentrations were involved. In these, mannitol found to be an inferior carbon source, irrespective of the concentration in nutrient pool. Due to this, shoot buds sprouting and multiplication is not seen (Bhojwani and Razdan, 1996). Cultures grown on mannitol-enriched medium showed poor multiplication with shortest shoot length in 'Nendran' banana (Madhulatha et al., 2006).

Fructose which is followed by sucrose is found to be the most suitable carbon source for shoot multiplication response. And fructose also found to be superior for other growth parameters like shoot thickness. The process of organogenesis is in great demand in terms of energy, so energy source is more accessible for plant cultures. The reports have been proved that fructose is more accessible energy source than sucrose (Torpe, 1980). The most commonly used carbon source for large number of plant 
species including banana is considered as sucrose (Hussein, 2012; Madhulatha et al., 2006). The conversion of sucrose into glucose and fructose is seen in cultures. A particular amount of sucrose is hydrolyzed into its component sugars during sterilization of media (Son et al., 2000).

Vora and Jasrai. (2011) reported that the fructose is most suitable sugar for inducing highest number of shoots (12.5 per explants) statistically in culture followed by tissue culture grade sucrose (10.8). The fructose-containing media showed superiority in 'Grand Naine' has reported by (Vora and Jasrai, 2011; Khafagy, 2007).

The studies also showed the effects of different concentrations of carbon sources on in vitro root induction. In $100 \%$ plantlets, root induction was favoured by the low concentrations of sugars. The cuttings which are rooted under ex vitro (field) conditions reduced nutrient strength and in order to the survival of plant these nutrients send signals to the cuttings for root induction (Hanumantharaya et al., 2011).

\section{ROLE OF DIFFERENT CONCENTRATIONS OF GROWTH HORMONES ON ROOTING}

Al-Amin et al. (2009) reported root initiation in banana cV. BARI-1 by using the half strength MS medium supplemented with different concentrations of IBA $(0,0.5$, 1.0 and $1.5 \mathrm{mg} / \mathrm{l})$ and IAA $(0,0.5$, and $1.0 \mathrm{mg} / \mathrm{l})$. The combination of $0.5 \mathrm{mg} / \mathrm{l}$ IAA and $0.5 \mathrm{mg} / \mathrm{l}$ IBA showed the highest number of roots (6.50) and the longest length of root $(5.88 \mathrm{~cm})$. The multiplicated shoots of banana cv. Grand Naine were inoculated on rooting media incorporated with either IBA or NAA $(0.25,0.5,1.0,2.0$, 2.5 and $3.0 \mathrm{mg} / \mathrm{l})$ and charcoal $(2 \mathrm{~g} / \mathrm{l})$ for root induction. These IBA (2mg/l) and charcoal (2g/l) produced maximum number of roots (8.5) with a lot of root hairs (Rai et al., 2012).

Anbazhagan et al. (2014) found that the half strength MS medium supplemented with IBA at $1.0 \mathrm{mg} / \mathrm{l}$ resulted in best root formation (96\%) and root number / explants (11.80) of in vitro developed shoots of Musa spp. The rooting on MS medium (half strength) combined with IBA $1.0 \mathrm{mg} / \mathrm{l}$ and activated charcoal 200mg/l obtained best rooting (Ahmed et al., 2014). The rooting experiments involving the use of IAA, IBA, NAA, smoke-water (SW) and karrikinolide (KAR1) were conducted. SW and KAR1 showed the significant increase in the number and length of roots. As compared to BA, the usage of topolin resulted higher mean shoot number per explants at lower cytokinin concentrations and the ease of rooting during the shoot proliferation phase (Aremu et al., 2012).

Jamir and Maiti (2014) studied the effect of IBA and NAA on rooting of banana cultivars Grand Naine and Jahaji. NAA and IBA at the concentrations of $(0,0.1,0.2$, and $1 \mathrm{mg} / \mathrm{l})$ were used individually for rooting purpose. The medium with 1mg/l NAA showed the cent percent rooting and highest no. of functional roots (6.33 and 5.2) with moderate root length $(2-4 \mathrm{~cm})$.

\section{CONCLUSION}

Plant growth regulators play a prominent role in the tissue culture technology. Mostly the generalisations about the plant growth regulators and their use in the plant cell culture media have been developed from the initial observations which are made in the 1950s. Some considerable difficulty in predicting the effect of plant growth regulators because of the great difference in the culture response between the species, cultivars and even some plants of the same cultivar are grown under different conditions. However, some principles do hold true and have become the paradigm on which most plant tissue culture regimes are based.

Out of these, auxins and cytokinins are the most widely used growth hormones in the plant tissue culture. In most of the cases, these both hormones are used together for the proper growth and development. The optimum concentrations of BAP resulted in better shooting of the explants and the optimum concentrations of IBA showed better rooting as compared to the other growth hormones. Some carbon sources like glucose, sucrose and fructose are also involved in the rooting and shooting of the banana explants. Among these, fructose is considered to be the most suitable sugar for shooting.

\section{REFERENCES}

1. Ahmed, S., Sharma, A., Bhushan, B., Singh, A.K. Wali, V. K. and Singh, A. K. (2014). Studies on hardening and acclimatization of micropropagated plantlets of banana cv. Grand Naine. The Bioscan, 9(3): 965-967.

2. Al-Amin, M. D., Karim, M. R., Amin, M. R., Rahman, S. and Mamun, A. N. M. (2009). In vitro micro propagation of banana (Musa spp.). Bangladesh Journal of Agricultural Research, 34(4): 645-659.

3. Alexandrova, K., Denchev, P. and Conger, B. (1996). Micropropagation of Switchgrass by Node Culture. Crop Science. 36, 1709-1711. 
4. Anbazhagan, M., Balachandran, B. and Arumugam, K. (2014). In vitro propagation of Musa spp. (Banana). International Journal Current Microbiology and Applied Sciences, 3(7): 399-404.

5. Aremu, A. O., Bairu, M. W., Szu“čova', L., Doležal, K., Finnie, M. J. F. and Staden, J. V. (2012). Assessment of the role of meta-topolins on in vitro produced phenolics and acclimatization competence of micro propagated 'Williams' banana. Acta Physiologiae Plantarum. 34: 2265-2273.

6. Asmare Dagnew, Surafel Shibru, Abel Debebe, Alemshet Lemma, LemmaDessalegn, Behailu Berhanu, Worku Beyene and Yulien Miguelez Sierra, Melkassa (2012). Micro propagation of Banana Varieties (Musa spp.) Using Shoot-Tip Culture.Ethiop. J. Agric. Sci. 22:14-25.

7. Bhojwani SS, Razdan MK. (1996). Plant tissue culture: theory and practice. Elsevier, Amsterdam, The Netherlands, p 48.

8. Bohidar, S., Thirunavoukkarasu, M. and Rao, T. (2008) Effect of Plant Growth Regulators on in Vitro Micropropagation of 'Garden Rue' (Ruta graveolens L.). International Journal of Integrated Biology. 3, 36-43.

9. Carreel. F, D Gonzalez de Leon, P Lagoda, C Lanaud, C Jenny, J P Horry, H Tezenas du Montcel. (2002). Ascertaining maternal and paternal lineage within Musa by chloroplast and mitochondrial DNARFLP analyses. Genome. 45(4), 679-692.

10. Ferdous, M. H., Masum Billah, A. A., Mejraj, H., Taufique, T. \& Jamal Uddin, A. F. M. (2015). BAP and IBA pulsing for in vitro multiplication of banana cultivars through shoot-tip culture. Journal of Bioscience and Agriculture Research. 03(02): 87-95.

11. Forsyth, W.G.C. (1980). Banana and Plantain. Tropical and subtropical fruits, Nagy, S., \& Shaw, P.E., eds., AVI Publishing, Westport, CT, 258-278.

12. G. Arinaitwe, P. R. Rubaihayo and M. J. S. Magambo. (2000). "Proliferation Rate Effects of Cytokinins on Banana (Musa spp.) Cultivars," Scientia Horticulturae. 86(1), 13-21.

13. Gübbük, H. and Pekmezci, M. (2004) In Vitro Propagation of Some New Banana Types (Musa spp.). Turkish Journal of Agriculture and Forestry. 28, 355361.

14. Hanumantharaya BG, Sathyanarayana BN, Waman AA. (2011). Reduced media salt concentration improves in vitro rooting in Indian pennywort. J Cell Tissue Res. 11:2771-2774.

15. Hussein, N. (2012) Effects of Nutrient Media Constituents on Growth and Development of Banana (Musa spp.) Shoot Tips Cultured in Vitro. African Journal of Biotechnology. 11, 9001-9006.

16. Ikram-ul-Haq and M. U. Dahot. (2007). "MorphoPhysiological Aspects of Micro-Propagating Banana under Different Hormonal Conditions,”. Asian Journal of Plant Sciences. 6(3), 496-501.

17. Indian Horticulture Database (2014). National Horticulture Board, Ministry of Agriculture, Government of India. Aristo Printing Press, India, 4-5. http://nhb.gov.in/report_files/banana/BANANA.htm.

18. J. N. Buah, E. Danso, K. J. Taah, E. A. Abole, E. A. Be- diako, J. Asiedu and R. Baidoo. (2010). "The Effects of Different Concentrations Cytokinins on the in Vitro Multiplication of Plantain (Musa sp.)," Biotechnology. 9(3), 343-347.

19. Jamir, S. and Maiti, C. S. (2014). Effect of various levels of cytokinin and auxin for in- vitro regeneration of banana cultivars. International Journal of Agriculture Innovations and Research. 2(6): 11601163.

20. Khafagy SAA. (2007). Effect of different carbon source concentrations on in vitro proliferation and rooting of Grande Naine banana plantlets. Egypt $J$ Appl Sci. 22:504-511.

21. Kromer, K., Kukulczanka, K. (1985). In vitro cultures of meristem tips of Canna indica L. Acta Hortic. 167: 279-285.

22. Lalonde S, Boles E, Hellman H, Barker L, Patrick J.W., Frommer W.B., Ward J.W. (1999). The dual function of sugar carriers: transport and sugar sensing. Plant Cell. 11:707-726.

23. Lehmann Undine., Gisela Jacobasch., Detlef Schmiedl. (2002). Characterization of resistant starch type III from banana (Musa acuminata). Journal of Agriculture and Food Chemistry. 50 (18), 5236-5240.

24. Madhulatha P, Kirubakaran SI, Sakthivel N. (2006). Effects of carbon sources and auxins on in vitro propagation of banana. Biol Plant. 50:782-784.

25. Mante, S., Tepper, H. B. (1983). Propagation of Musa textilis Nee plants from apical meristem slices in vitro. Plant cell, tissue and organ culture. 2: 151-159.

26. N. Jafari, R. Y. Othman and N. Khalid. (2011). "Effect of Ben-zylaminopurine (BAP) Pulsing on in 
Vitro Shoot Multi- plication of Musa acuminata (Banana) cv. Berangan," African Journal of Biotechnology. 10(13), 2446-2450.

27. Onildo Nunes de Jesus, Sebastiao de Oliveira e Silva, Edson Perito Amorim, Claudia Fortes Ferreira, Jose Marcello Salabert de Campos, Gabriela de Gaspari Silva, Antonio Figueira. (2013). Genetic diversity and population structure of Musa accessions in ex situ conservation. BMC Plant Biology. 13(41), 1-22.

28. P. Madhulatha, M. Anbalagan, S. Jayachandran and N. Sakthivel. (2004). "Influence of Liquid Pulse Treatment with Growth Regulators on in Vitro Propagation of Banana (Musa spp. AAA),”. Plant Cell Tissue Organ Culture. 76(2), 189-192.

29. Pillay, M., Ogundiwin. E., Tenkouano. A., Dolezel. J. (2006). Ploidy and genome composition of Musa germplasm at the International Institute of Tropical Agriculture (IITA). African Journal of Biotechnology. 5(13), 1224-1232.

30. Raghavendar G, Khannam A and Rathore TS (2019). An efficient protocol for in vitro propagation of mimosa pudica l., - a medicinally important plant species. International Journal on Agricultural Sciences. 10 (1 \& 2):29-33.

31. Rai, M., Mittal, P., Kaur, A. Kaur, G., Gaur, I. and Singh, C. (2012). In Vitro regeneration of banana variety Grand Naine (G9). Trends in Biosciences. 5 (3): 176-179.

32. S. Shirani, F. Mahdavi and M. Maziah. (2011). "Morphological Abnormality among Regenerated Shoots of Banana and Plantain (Musa spp.) after in Vitro Multiplication with TDZ and BAP from Excised Shoot Tips. African Journal of Biotechnology. 8(21), 5755- 5761.

33. Sazedur Rahman, Nirupam Biswas, Md. Mehedi Hassan, Md. Golam Ahmed, ANK Mamun, Md. Rafiqul Islam, Md. Moniruzzaman, Md. Enamul
Haque. (2013). Micro propagation of banana (Musa sp.) cv. Agnishwar by In vitro shoot tip culture. International Research Journal of Biotechnology. 4(4), 83-88.

34. Shahnawaz Ahmed, Akash Sharma, A.K. Singh, V.K. Wali and Preeti Kumari (2014). In vitro multiplication of banana (Musa spp.) cv. Grand Naine, 13(27), 2696-2703.

35. Simmonds, N.W., \& Shepherd, K. (1955). The taxonomy and origins of the cultivated bananas. Bot. J. Linn. Soc. 55(359), 302-312.

36. Son SH, Choi SM, Lee YH, Choi KB, Yun SR, Kim JK, Park HJ, Kwon OW, Noh EW, Seon JH, Park YG. (2000). Large scale growth and taxane production in cell cultures of Taxus cuspidata (Japanese yew) using a novel bioreactor. Plant Cell Rep. 19:628-633.

37. Torpe TA. (1980). Perspective in plant cell and tissue culture. In: Vasil IK (Ed) Supplement IIA. Academic, New York.

38. Venkatachalam, L. (2008). Molecular characterization of banana var. Najanagudu Rasabale and identification of fruit ripening specific products. Ph. D Thesis, Department of Biotechnology, University of Mysore India.

39. Vora NC, Jasrai YT. (2011). Effect of various carbon sources on in vitro shoot multiplication of banana. Phytomorphology. 61:111-116.

40. Vuylsteke, D.R. (1989) "Shoot-Tip Culture for the Propagation, Conservation and Exchange of Musa germplasm,” IBPGR, Rome.

41. W.C. Wong (1986). In vitro propagation of banana (Musa spp.): initiation, proliferation and development of shoot-tip cultures on defined media. Plant Cell, Tissue and Organ Culture. 6:159-166.

42. Zaffari, G. R., Kerbauy, G. B., Kraus, J. E., Romano, E. C. (2000). Hormonal and histological studies related to in vitro banana bud formation. Plant Cell Tiss. Org. Culture. 63: 187-192. 